\title{
The Association Between Corporate Tax Avoidance And Audit Efforts: Evidence From Korea
}

\author{
Seong Ho Bae, Ph.D., Kyungpook National University, South Korea
}

\begin{abstract}
The purpose of this paper is to verify external auditors' behavior toward corporate tax avoidance (hereafter 'CTA') via audit efforts. In particular, this study examines the effect of CTA on actual audit hours and abnormal audit hours (i.e., auditor perception of corporate tax avoidance as a risk factor).

For the successful CTA, the managers have incentives to render corporate information environments more complex and opaque, and as a result exacerbate information asymmetries. And some real-world cases of CTA suggest that it is closely related to the principal-agent regime. These negative aspects of CTA may increase inherent and control risk of audit risks. Considering the monitoring role of external auditing, the auditors may respond to increased inherent and control risks which are consequent to CTA. And the auditor responses are expected to reflect directly in audit hours. For this empirical question, this paper used 2,588 firm-year observations from Korea stock exchange market in the period 2001-2010. We found that in response to increased audit risk from CTA, auditors increased the number of actual audit hours or devoted more audit hours than normal to achieve a given level of audit risk.

This study contributes to the literature and auditing practices by extending the auditing and tax literature on the examination of auditor behavior toward CTA and by implying the firms' CTA behavior is one of the audit risk factors that affect audit planning, respectively.
\end{abstract}

Keywords: Corporate Tax Avoidance; Information Asymmetry; Agency Problem; Audit Risk; Audit Effort

\section{INTRODUCTION}

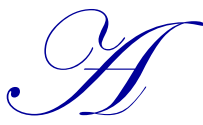
ccording to prior studies, corporate tax avoidance (hereafter 'CTA') is broadly regarded as the reduction of explicit taxes via legal tax planning or illegal sheltering (Hanlon and Heitzman 2010). Intuitively, it is considered as a beneficial strategy for firm shareholder value by minimizing tax payments to the state and preserving firm resources. Despite the positive side of CTA, it may involve information asymmetry around the firm and agency conflict between manager and other parties.

With respect to information asymmetry, CTA apparently includes tax noncompliance and legal tax planning. Since legal strategies such as investing in tax-beneficial bonds are well-known and do not create distinct advantages in minimizing tax payments, it is difficult to say that tax planning within legal boundaries forms a crucial part of CTA. Therefore, it is reasonable that CTA exists in grey areas between lawful and unlawful actions and judgment as to legality depends on the eyes of the beholder. In this regard, the firm bears risks regarding CTA as to whether its tax strategies are deemed to be legal or illegal by interested parties, and the managers have incentives to control the information flows and keep specific tax planning secret from interested parties. Furthermore, the detection risk of concrete tax schemes by tax authorities or shareholders whose interests are not necessarily aligned with managers, could force managers to make tax-related transactions more complex and information environments more opaque. Therefore, CTA is inherently related to information asymmetry.

Regarding the linkage between CTA and agency conflicts, the separation of ownership and control is one of the crucial characteristics of firms and the manager's self-interest does not always align with that of shareholder (Jensen and 
Meckling 1976). Also, considering the fact that decisions of specific tax strategies are made mostly by managers (Slemrod 2004), it is probable that, to some extent, CTA is related to agency problems. Moreover, in connection with the information properties of CTA, it cannot exclude the possibility that self-interested managers have incentives to resort to rent-diversion via aggressive tax planning. To successfully implement their tax strategy, senior Tyco executives controlled the information stream and as a result only a handful of individuals actually understood the full workings of Tyco (Desai 2005). The managers' self-interest combined with this information asymmetry caused serious managerial frauds under the guise of CTA: abuse of corporate funds for personal purpose, abuse of loan programs, unauthorized compensation, and related party transactions what were established for the purpose of tax avoidance. Thus, CTA is closely related to the principal-agent regime and can be a way for self-interested managers to engage in rent-diversion.

This paper aims to investigate auditor behavior toward CTA via audit hours. First of all, the negative attributes of CTA such as information asymmetry and agency problem will increase audit risk. ${ }^{1}$ From an auditing perspective, if auditors recognize specific tax strategies of client firms, they should evaluate the future consequences of grey tax planning and incorporate such issues with appropriate procedures (e.g., restatement of financial statements). However, managers have incentives to conceal their detailed procedures of tax planning from outside parties and as a result may plot some tax schemes via complex record keeping or intentional accounting frauds by overriding internal controls to the extent that even external auditors may not notice. This managerial misdeed, which is contrary to integrity or truthfulness, increases inherent risk and control risk. Therefore, this study examines auditor responses to increased audit risk from CTA through audit efforts.

To examine our hypotheses regarding auditor behavior toward CTA, multiple measurements in corporate tax avoidance are adopted based on previous tax research. Specifically, we use following CTA measures; one year of GAAP and cash effective tax rates (Dhaliwal et al. 2011; McGuire et al. 2012), three years of long-run GAAP and cash effective tax rates (Dyreng et al. 2008), discretionary book-tax differences (Desai and Dharmapala 2006) and total book-tax differences (Wilson 2009). As a proxy for auditor effort, actual audit hours and estimated abnormal audit hours are used. The actual audit hours cited here were collected from annual reports and the estimated abnormal audit hours are derived from residuals by regressing the actual audit hours on the factors that affect audit hour determination, which is a similar approach to estimating abnormal audit fees (Hope et al. 2009; Choi et al. 2010).

Using 2,588 firm-year observations from $\mathrm{KOSPI}^{2}$ in the period 2001-2010, the main results are as follows. First, in response to the increased audit risk from CTA, auditors increased the actual audit hours or devoted more audit hours than normal to reduce audit risk to a given level. For robustness check, factor analysis and time lag analysis have been performed, the additional findings of which support our main results.

This study contributes to the literature and auditing practices in the following ways. Firstly, it provides evidence that CTA is related to auditor behavior. While recent tax studies mostly emphasize the factors that affect corporate tax avoidance (Chen et al. 2010; Dyreng et al. 2010; McGuire et al. 2012) and the negative impact of corporate tax avoidance on capital markets (Dhaliwal et al. 2011; Kim et al. 2011; Balakrishnan et al. 2011), this research deals with associations among CTA, audit risk and auditor response to such relation. As such, this paper adds to the relatively scarce corpus of information regarding auditor behaviors toward CTA. Secondly, on the perspective of auditing practices, this paper suggests that the incumbent external auditors should adjust their audit efforts through consideration on the level of clients' CTA. So our results imply that the firms' corporate tax avoidance behavior is one of the audit risk factors that affect audit planning.

The rest of this paper proceeds as follows. Section 2 reviews prior research and presents hypotheses. Research design and sample are described in Section 3. Section 4 presents empirical results and Section 5 reports additional analyses. Section 6 concludes.

\footnotetext{
${ }^{1}$ The audit risk is the risk that the auditor expresses an inappropriate audit opinion when the financial statements are materially misstated. The audit risk is described as a function of the inherent risk, control risk, and detection risk (Bell et al. 2006).

${ }^{2}$ Korean stock exchange market is comprised of KOSPI (Korea Composite Stock Price Index) and KOSDAQ (Korea Securities Dealers Automated Quotations) which is comparable to NYSE (New York Stock Exchange) and NASDAQ (National Association of Securities Dealers Automated Quotation) in the U.S., respectively.
} 


\section{PROIR RESEARCH AND HYPOTHESIS DEVELOPMENT}

\section{Corporate Tax Avoidance and Information Environments}

CTA encompasses a range of strategies from legal tax planning to illegal sheltering and it is broadly regarded as the reduction of explicit taxes (Dyreng et al. 2008; Hanlon and Heitzman 2010). Intuitively, it is considered as a beneficial strategy for shareholders as it minimizes tax payments to the state and preserves firm resources. Even though firms could save resources via tax avoidance, it may involve information asymmetry within the firm and agency conflict between management and other parties.

For successful CTA, managers have incentives to make corporate information environments more complex and opaque and as a result exacerbate information asymmetries. Considering the possibility of CTA, which includes extensively illegal non-tax compliance and legal tax planning, outsiders may lack knowledge about detailed tax strategies. In particular, it is difficult to say that tax planning within the legal boundaries is a crucial part of CTA because legal activities such as investing in tax-beneficial bonds are anticipated as par for the course and indeed taught in corporate tax courses. In other words, tax strategies regarded as routine do not create a distinct advantage in minimizing tax payments. Therefore, it is reasonable that the CTA exist in the grey areas between what is lawful and unlawful. But judgment on legality depends on the beholder, and practitioners will often hold conflicting opinions (Hanlon and Heitzman 2010). In this regard, the firm bears the onus regarding CTA as to whether its tax strategies are deemed legal or illegal by interested parties. For example, the legitimacy of transfer pricing strategy with foreign subsidiaries is determined on a case-by-case basis.

It is expected that managers, concerned about the exposure of detailed tax strategies, have incentives to control information flows and strive to keep specific planning secret from interested parties such as the IRS (Internal Revenue Service). Furthermore, the detection risk of tax avoidance by the tax authorities or shareholders whose interests are not aligned with managers could force the managers to make tax-related transactions more complex and information environments more opaque. That might be the reason that many researchers and tax authorities have regarded CTA as necessarily including illegal factors to some extent or intentional behavior by managers to evade tax laws (Hanlon and Heitzman 2010).

Some real-world cases provide evidence regarding informational properties of CTA. In the Tyco case, complex transactions with foreign subsidiaries in tax haven were intentionally designed by managers for the sole purpose of defeating or obstructing tracking or detection by outside parties. Such transactions are intended to create inequality in information environments between insiders and outsiders and thereby aggravate information asymmetry as far as the firm is concerned. Therefore, it is probable that even the insiders of firm or incumbent auditors may not fully understand the complex transactions arising from CTA. Also, Kim et al. (2011) argue that CTA is positively associated with the intent by managers to hoard or obfuscate negative news. This means that managers intentionally intervene in the firms' information environment for tax strategies.

Consequently, CTA is closely related to the information environment, and can give rise to information asymmetry among the interested parties.

\section{Corporate Tax Avoidance and Agency Framework}

Slemrod (2004) highlights the differences between individual tax planning and CTA and argues that the latter needs to be dealt with under the principal-agent framework. Since the separation of ownership and control is one of the crucial characteristics of firms (Jensen and Meckling 1976), a manager's private interests do not always align with those of the shareholders. Moreover, the fact that decisions behind specific tax strategies are made mostly by managers suggests the possibility that CTA involves agency problems. Under the premise that a firm seeks to evade its tax burden with risk-neutral principals and risk-averse managers, Chen and Chu (2005) argue that ex-ante a manager's unfair compensation contract does not fully reflect tax evasion risk because successful tax evasion guarantees a manager's incentive compensation for his efforts whereas a manager cannot expect any reward or even bears punishment risk for illegal acts when tax evasion is detected. So, CTA incurs efficiency loss in controlling the manager's effort and thereby entails principal-agent conflicts. 
The CTA may impact firm value negatively when we focus on the manager's self-interested properties in principalagent regime. As mentioned earlier, CTA leads to complex transactions, information asymmetries and information monopoly on the part of very few persons. Therefore, it is possible that such information opaqueness is misused for private purpose by personnel such as the CEO or CFO who designed the tax planning strategy. In other words, selfinterested managers may have incentives toward rent-diversion via CTA.

The Tyco case, one of the most notorious tax sheltering scandals in the U.S., supports the premised linkage between CTA and managerial rent-diversion by proposing several types of managerial misbehavior. To ensure the success of their tax strategy, Tyco senior executives controlled the information stream and as a result only a handful of individuals actually understood the full workings of Tyco (Desai 2005). The managers' self-interest combined with this information asymmetry caused serious managerial fraud under the name of CTA: the abuse of corporate funds for personal gain, loan program abuse, unauthorized compensation, related party transactions established for the purpose of tax avoidance and an array of misrepresentations associated with these activities and with trading in Tyco stock.

Further, Desai and Dharmapala (2006) focus on managerial diversion in tax sheltering and argue that to some extent principal-agent conflict, which cannot be aligned by compensation schemes, exist in CTA, and corporate governance influences a manager's tax planning decision. In a similar vein, Desai et al. (2007b) proffer evidence that strong tax enforcement that curtailed transactions with related parties or tax haven entities in Russia after the election of Vladimir Putin in 2000 increased tax payments as well as firm value. Thus, it is probable that CTA is related with the control environment, which influences the scope of managerial decisions and, in particular, the positive relation between government tax revenues and firm value, potentially implies managerial rent-diversion via tax sheltering. Regarding the possibility of managerial diversion, Dhaliwal et al. (2011) provide more direct proof. They regard firm cash holdings as a means of managerial rent extraction and find negative relation between CTA and firm cash holdings. In other words, low cash holdings are associated with managerial rent-diversion when the degree of CTA is high. These results confirm the possibility that CTA can be one variant of managerial private rent-seeking.

Collectively, CTA is closely related to the principal-agent regime and a firm's control environments and concomitantly a way for self-interested managers to engage in rent-diversion.

\section{Corporate Tax Avoidance and Audit Risk}

The information risk and agency problem from CTA may affect audit risk through increasing inherent risk and control risk. For information risk, it is expected that complexity and obfuscation from information asymmetry makes accounting difficult to comprehend and thereby increases inherent risk. Frank et al. (2009) argue that information risk from CTA deepens the uncertainty around the firms which confers on the manager greater flexibility in making accounting estimates for accruals. Moreover, Balakrishnan et al. (2011) contend that complex tax strategies and opaque transactions deteriorate earnings quality. These results imply that CTA can be a factor in increasing inherent risk.

To be more concrete on the management side, the managers are reluctant to expose specific tax planning for the understanding of interested parties. In the Tyco case, there were strict controls over information streams and only a handful of individuals such as the CEO or CFO actually understood the full workings of Tyco. In this context, it is probable that the managers plot some tax schemes so quietly that even the external auditors may not notice. For instance, if the incumbent auditors recognize any tax avoidance behavior of client firms which are of doubtful legality and debatable with the tax authorities in the future, they should evaluate the effects in the audit report and incorporate such issues with appropriate procedures ${ }^{3}$ (e.g., restatement of financial statements, modifying the audit report with explanatory paragraph). To fend off this possibility, the managers may exploit the misapplication of sampling basis auditing by adopting complex accounting practices or changing account titles intentionally. Such misdeeds increase inherent risk. Moreover, management factors such as integrity or truthfulness are one of the important determinants

\footnotetext{
${ }^{3}$ U.S. Auditing Standards Section 317: Illegal acts by clients: The auditors' response to detected illegal acts; U.S. Auditing Standards Section 508: Reports on audited financial statements.
} 
of inherent risk at the financial statements level. ${ }^{4}$ In this vein, managerial control over the information flows of firms may negatively impact inherent risk.

In a similar vein, the agency problem might increase both inherent risk and control risk. Regarding the agency regime, private rent-seeking behavior of managers, which conflict with shareholder interests, may adversely affect managerial integrity or truthfulness, potentially increasing inherent risk. Also, it is known that internal control systems invoke the possibility of managerial overriding. ${ }^{5}$ In connection with the agency regime, it is probable that managers record complex and opaque transactions in financial statements with overriding internal controls for their own private purpose under the name of effective tax planning. Hence, the agency problem from CTA could increase control risk.

Considering the role of auditing in the financial market, information asymmetry and the agency problem should be mitigated by effective monitoring. Pittman and Fortin (2004) argue that the monitoring role of auditing mitigates information asymmetry and enhances the credibility of financial statements. Also, Lennox (2005) suggests that the auditor's monitoring function plays an important role in the agency framework. Furthermore, the auditors are susceptible to increased audit risk because they are concerned about audit failure which increases litigation risk or reputational depreciation (Palmrose 1988). The PricewaterhouseCoopers audit guidance proposes that auditors should conduct analytical reviews on a firm's effective tax rate to evaluate the extent of materiality and inherent risk in controls tests and substantive tests (PwC Audit Guidance 5700 Income Tax). Such procedures are designed to assist auditors to perceive increased audit risk from corporate tax avoidance.

Building on the above arguments, it is anticipated that auditors may respond to increased inherent and control risks which are consequent to corporate tax avoidance and auditor responses are directly reflected in audit hours. Because auditors need to expend more effort to detect errors in risky financial statements, more audit hours are required (Palmrose 1989; Davis et al. 1993). Therefore, if the auditors perceive additional audit risk from CTA, it is expected that auditors will devote more audit hours to achieve a given level of audit risk ${ }^{6}$. Hence, we test the following hypothesis in an alternative form:

$\mathbf{H}_{1-1}$ : Firms with a high level of corporate tax avoidance will incur more audit hours, other factors being equal.

Audit hours are regarded as reasonable proxy for audit efforts and mainly determined by factors that are common across different clients such as size, complexity, and specific risk (Caramanis and Lennox 2008). Considering that abnormal audit fees are determined by factors that are idiosyncratic to a specific auditor-client relationship and often interpreted as an auditor economic bonding with clients (Hope et al. 2009), it is expected that abnormal audit hours reflect additional audit effort to compensate for idiosyncratic client risk factors. If auditors perceive additional audit risk from CTA, it is expected that they are more likely to devote more audit hours than normal to achieve a given level of audit risk. Hence, we test the following hypothesis in alternative form:

$\mathrm{H}_{1-2}$ : Firms with a high level of corporate tax avoidance will involve more abnormal audit hours, other factors being equal.

\footnotetext{
${ }^{4}$ U.S. Auditing Standards Section 312: Audit risk and materiality in conducting an audit: Planning the audit.

${ }^{5}$ U.S. Auditing Standards Section 318: Understanding of the entity and its environment and assessing the risks of material misstatement.

${ }^{6}$ Comparing this study to Donohoe and Knechel (2014) which mainly focuses on the impact of CTA on audit fees, this study examines the impact of CTA on actual (abnormal) audit hours. The audit hours reflect auditors' efforts directly, whereas audit fees are determined by auditor's cost factors such as efforts and also client-specific risk factors (Simunic 1980). Moreover, audit fees are affected by pricing factors as the relationship with clients, market competition, or level of non-audit service fees from incumbent auditors (Niemi 2002). So we cannot exclude the possibility that increasing audit fees do not involve necessarily increasing auditor's efforts. And we can expect that audit hours are more appropriate proxy than audit fees to capture auditor's perceptions and response toward CTA.
} 


\section{RESEARCH DESIGN AND SAMPLE}

\section{Model Specification}

Actual Audit Hour Model and Variables

To examine the $\mathrm{H}_{1-1}$ which is regarding the impact of CTA on actual audit hours, we posit the following model:

$$
\begin{aligned}
& L N_{-} \text {Audit Hour }{ }_{\mathrm{i}, \mathrm{t}}=\alpha 0+\alpha 1 T A V_{I \sim 6 \mathrm{i}, \mathrm{t}}+\alpha 2 S I Z E_{\mathrm{i}, \mathrm{t}}+\alpha 3 A D T_{\mathrm{i}, \mathrm{t}}+\alpha 4 C O N_{\mathrm{i}, \mathrm{t}}+\alpha 5 I N V R E C_{\mathrm{i}, \mathrm{t}}+\alpha 6 E X P R_{\mathrm{i}, \mathrm{t}} \\
& +\alpha 7 I S S U E_{\mathrm{i}, \mathrm{t}}+\alpha 8 L I Q_{\mathrm{i}, \mathrm{t}}+\alpha 9 L E V_{\mathrm{i}, \mathrm{t}}+\alpha 10 A O P_{\mathrm{i}, \mathrm{t}-1}+\alpha 11 R O A_{\mathrm{i}, \mathrm{t}}+\alpha 12 L O S S_{\mathrm{i}, \mathrm{t}}+\alpha 13 G R W_{\mathrm{i}, \mathrm{t}}+\alpha 14 F I R S T_{\mathrm{i}, \mathrm{t}} \\
& +\alpha 15 O W N_{\mathrm{i}, \mathrm{t}}+\alpha 16 F O R_{\mathrm{i}, \mathrm{t}}+\text { Year fixed }+ \text { Industry fixed }+e_{\mathrm{i}, \mathrm{t}}
\end{aligned}
$$

where, for client firm $i$ in year $t$, and the definition of variables are as follows:

$L N \_$Audit Hour $=$natural $\log$ of actual audit hours;

$T A V_{I \sim \sigma}=$ six CTA measurements;

$S I Z E=$ natural log of total assets;

$A D T=$ ' 1 ' if the firm's auditor is a Big 4 , and ' 0 ' otherwise;

$C O N=$ ' 1 ' if the firm discloses audited consolidated financial statements, and

' 0 ' otherwise;

$I N V R E C=$ ratio of the sum of inventory and account receivable divided by total assets;

$E X P R=$ ratio of export sales to total sales;

$I S S U E=$ ratio of debt and stock issuance to beginning total assets;

$L I Q=$ ratio of current assets to current liabilities;

$L E V=$ ratio of debt to total assets;

$A O P=$ ' 1 ' if the audit opinion is not unqualified, and ' 0 ' otherwise;

$R O A=$ ratio of net income to total assets;

$L O S S=$ ' 1 ' if the firm reported net loss and ' 0 ' otherwise;

$G R W=$ sales growth, difference between current fiscal year of sales and prior fiscal year of sales scaled by prior fiscal year of sales;

$F I R S T=$ ' 1 ' if an audit is a first-year engagement, and ' 0 ' otherwise;

$O W N=$ percentage of shares held by largest shareholders;

$\mathrm{FOR}=$ percentage of shares held by foreign shareholders;

Year fixed=dummy variables controlling for fixed effects of year; and

Industry fixed = dummy variables controlling for fixed effects of industry. 
Equation (1) is based upon the extant studies on audit hours (O'Keefe et al. 1994; Caramanis and Lennox 2008; Sohn et al. 2008) and the various factors that affect audit hours such as firm size, firm characteristics, complexity, and risk are included as control variables.

Our main variable is CTA $\left(\mathrm{TAV}_{\mathrm{i}, \mathrm{t}}\right)$ and six measurements are adopted to capture the degree of firm's tax avoidance. Since each approach have its own strength and depending on a single measure of CTA may lead to spurious conclusions (Hanlon and Heitzman 2010; Dhaliwal et al. 2011), multiple measurements are used in this paper. They are 'GETR_1Y', 'CETR_1Y', 'GETR_3Y', 'GETR_3Y', 'DD_BTD', and 'BTD'. The first four measurements are effective tax rates which are widely used in previous studies (Stickney and McGee 1982; Zimmerman 1983; Rego 2003; Richardson and Lanis 2007). Even though effective tax rates cannot capture all of the tax avoidance behaviors, they are easy to calculate. Especially, the effective tax rates are utilized by the auditors when they conduct the analytical review on the materiality or audit risk (PwC Audit Guidance 5700 Income Tax). In this regard, effective tax rates accord with our research purpose. The second two measurements are basically based on book-tax difference approach. The 'DD_BTD' captures tax reporting aggressiveness from the total book-tax differences whereas the 'BTD' regards the total book-tax differences as CTA. Therefore, 'DD_BTD' is less observable than 'BTD', but 'BTD' has limitation in representing pure CTA in that it includes not only opportunistic tax behaviors but also aggressive financial reporting. Notwithstanding these pros and cons, the last two measurements are adopted as supplemental indexes in this paper.

Concerning the effective tax rates, the lower number of effective tax rates are interpreted as higher level of CTA. So, it is expected that the audit hours are negatively associated with effective tax rates (i.e., $\alpha 1<0$ ). Since the effective tax rates have been distinguished as GAAP effective tax rate and CASH effective tax rate for the definition of numerator (Stickney and McGee 1982; Zimmerman 1983; Wilson 2009), we use both methodologies. The 'GETR_1Y' ('CETR_1Y') is GAAP (CASH) effective tax rate for a single year and calculated by tax expense (cash taxes payment) of current year divided by pre-tax income of current year.

$$
\text { GETR_IY } Y_{\mathrm{i}, \mathrm{t}}\left(C E T R_{-} 1 Y_{\mathrm{i}, \mathrm{t}}\right)=\text { Current tax expense } e_{\mathrm{i}, \mathrm{t}}\left(\text { Cash taxes payment } \mathrm{i}_{\mathrm{i}, \mathrm{t}}\right) / \text { Pre-tax } \text { income }_{\mathrm{i}, \mathrm{t}}
$$

But such single year of effective tax rate approach may have limitations because long time period measure tracks more closely firms' tax costs over long run (Dyreng et al. 2008; Balakrishnan et al. 2011). Moreover, effective tax rates for the past few years are used in auditors' analytical review on audit risk evaluation. So, we adopt the 'GETR_3Y' ('CETR_3Y') which is the effective tax rate for three years and calculated by sum of tax expense (sum of cash taxes payment) for three years divided by sum of pre-tax income of three years.

$$
\begin{aligned}
& \text { GETR_3 } 3 Y_{\mathrm{i}, \mathrm{t}}\left(C E T R \_3 Y_{\mathrm{i}, \mathrm{t}}\right)=\text { Sum of current tax expense (cash taxes payment) for consecutive prior } \\
& \text { three years } \\
& \mathrm{i}, \mathrm{t}
\end{aligned}
$$

In the recent literature, 'DD_BTD' is regarded as more appropriate approach to capture the firm's aggressive tax planning (Desai and Dharmapala 2006; Hanlon and Heitzman 2010). Based on the Desai and Dharmapala (2006), 'DD_BTD' is derived as the residuals of following OLS model:

$$
B T_{\mathrm{i}, \mathrm{t}}=\beta 1 T A_{\mathrm{i}, \mathrm{t}}+\varepsilon_{\mathrm{i}, \mathrm{t}}
$$

where,

$\mathrm{BT}_{\mathrm{i}, \mathrm{t}}=$ book-tax difference for firm $i$ in year $t$, scaled by lagged value of assets;

$\mathrm{TA}_{\mathrm{i}, \mathrm{t}}=$ total accruals for firm $i$ in year $t$, scaled by lagged value of assets; and

$\varepsilon_{\mathrm{i}, \mathrm{t}}=$ residuals that cannot be explained by variations in total accruals.

The high level of 'DD_BTD' is interpreted as high level of corporate tax avoidance. So, it is expected that the audit hours are positively associated with 'DD_BTD' (i.e., $\alpha 1>0$ ). Regarding the book-tax difference which is principally based on Manzon and Plesko (2002), earnings before income tax is adopted as book income, and taxable income is 
estimated based on gross-up method that is current tax expense grossed up by statutory tax rate (Hanlon 2005). Taxable income is estimated by following model:

$$
\mathrm{ETI}_{\mathrm{i}, \mathrm{t}}=A C T E_{\mathrm{i}, \mathrm{t}} / S T R_{\mathrm{t}}
$$

where,

$\mathrm{ETI}_{\mathrm{i}, \mathrm{t}}=$ estimated taxable income for firm $i$ in year $t$

$\mathrm{ACTE}_{\mathrm{i}, \mathrm{t}}=$ adjusted current tax expense for firm $i$ in year $t$, current income tax expense + (ending balance of deferred tax asset - beginning balance of deferred tax asset) - (ending balance of deferred tax liability - beginning balance of deferred tax liability); and

$\mathrm{STR}_{\mathrm{t}}=$ statutory corporate income tax rate of Korea in year $t^{7}$

We include changes of deferred tax asset and liability in $\mathrm{ACTE}_{\mathrm{i}, \mathrm{t}}$ to estimate more closely taxable income, and total accruals are derived from the difference between net income and cash flows from operating (Hribar and Collins 2002).

Lastly, the 'BTD' is adopted as proxy of CTA in some studies (Mills 1998; Wilson 2009), but it may not reflect the degree of tax avoidance. Based on the fact that book-tax difference are composed of book income and taxable income, it is unclear that large book-tax difference may be the product of aggressive accounting reporting (i.e., increasing accounting income) or aggressive tax reporting (i.e., decreasing taxable income). In spite of such limitations, we adopt 'BTD' for the comparison purpose, and expect positive association between 'BTD' and audit hours (i.e., $\alpha 1>0$ ). The 'BTD' is estimated by the differences of earnings before income tax and estimated taxable income according to Eq. (5).

\section{Abnormal Audit Hour Model and Variables}

To examine the $\mathrm{H}_{1-2}$ which is regarding the impact of corporate tax avoidance on abnormal audit hours, we estimate the abnormal audit hours with following model:

$$
\begin{aligned}
& L N_{\text {AAdit Hour }} \mathrm{i, \textrm {t }}=\gamma 0+\gamma 1 \operatorname{SIZE}_{\mathrm{i}, \mathrm{t}}+\gamma 2 A D T_{\mathrm{i}, \mathrm{t}}+\gamma 3 C O N_{\mathrm{i}, \mathrm{t}}+\gamma 4 I N V R E C_{\mathrm{i}, \mathrm{t}}+\gamma 5 E X P R_{\mathrm{i}, \mathrm{t}}+ \\
& \gamma 6 \overline{S S S U E}_{\mathrm{i}, \mathrm{t}}+\gamma 7 L I Q_{\mathrm{i}, \mathrm{t}}+\gamma 8 L E V_{\mathrm{i}, \mathrm{t}}+\gamma 9 A O P_{\mathrm{i}, \mathrm{t}-1}+\gamma \operatorname{IOROA}_{\mathrm{i}, \mathrm{t}}+\gamma 11 L O S S_{\mathrm{i}, \mathrm{t}}+\gamma 12 G R W_{\mathrm{i}, \mathrm{t}}+\gamma 13 \text { IRST }_{\mathrm{i}, \mathrm{t}}+ \\
& \gamma 14 O W N_{\mathrm{i}, \mathrm{t}}+\gamma 15 F O R_{\mathrm{i}, \mathrm{t}}+\text { Yearfixed }+ \text { Industry fixed }+\zeta_{\mathrm{i}, \mathrm{t}}
\end{aligned}
$$

where, for client firm $i$ in year $t$, and the definition of variables can be referred to the Eq. (1). The abnormal audit hours are derived as the residuals $\left(\zeta_{\mathrm{i}, \mathrm{t}}\right)$ by regressing the actual audit hours on the factors that affect audit hours and reflect additional auditors' effort to the clients (Sohn et al. 2008). And then we investigate the $\mathrm{H}_{1-2}$ with following OLS model:

$$
\begin{aligned}
& A B_{-} \text {Audit Hour } \mathrm{i}_{\mathrm{i}, \mathrm{t}}=\delta 0+\delta 1 T A V_{I \sim \sigma \mathrm{i}, \mathrm{t}}+\delta 2 S I Z E_{\mathrm{i}, \mathrm{t}}+\delta 3 A D T_{\mathrm{i}, \mathrm{t}}+\delta 4 C O N_{\mathrm{i}, \mathrm{t}}+\delta 5 I N V R E C_{\mathrm{i}, \mathrm{t}}+\delta 6 E X P R_{\mathrm{i}, \mathrm{t}} \\
& +\delta \overline{7} I S S U E_{\mathrm{i}, \mathrm{t}}+\delta 8 L I Q_{\mathrm{i}, \mathrm{t}}+\delta 9 L E V_{\mathrm{i}, \mathrm{t}}+\delta 10 A O P_{\mathrm{i}, \mathrm{t}-1}+\delta 11 R O A_{\mathrm{i}, \mathrm{t}}+\delta 12 L O S S_{\mathrm{i}, \mathrm{t}}+\delta 13 G R W_{\mathrm{i}, \mathrm{t}}+\delta 14 F I R S T_{\mathrm{i}, \mathrm{t}} \\
& +\delta 15 O W N_{\mathrm{i}, \mathrm{t}}+\delta 16 F O R_{\mathrm{i}, \mathrm{t}}+\text { Year fixed }+ \text { Industry fixed }+\mu_{\mathrm{i}, \mathrm{t}}
\end{aligned}
$$

where, for client firm $i$ in year $t$, and 'AB_Audit Hour ${ }_{\mathrm{i}, \mathrm{t}}$ ' is abnormal audit hours. The definition of other variables can be referred to the Eq. (1). Similar to Eq. (1), if the auditors response to the additional audit risk from clients' tax planning, 'AB_Audit Hour ${ }_{\mathrm{i}, \mathrm{t}}$ ' is expected to be negatively related with the 'GETR_1Y', 'CETR_1Y', 'GETR_3Y', 'GETR_3Y', and positively associated with the 'DD_BTD', and 'BTD'.

\footnotetext{
${ }^{7}$ Changes of statutory corporate income tax rate for sample period are as following. For the reference, the progressive tax rates are applied when corporate income taxation in Korea. And the base rate of KRW/USD on December 31, 2010 is 1,138.9 KRW to 1 USD, and thereby 100 million in KRW and 200 million in KRW are approximately 87,804 USD and 175,608 USD, respectively. See Appendix A.
} 


\section{Sample}

\section{Selection Criteria and Distributions}

Our final sample $e^{8}$ consists of 2,588 firm-years in the KOSPI from 2001 to 2010 . These are the firms that have the required data from the KIS-VALUE (for corporate tax avoidance measures and financial accounting information), the TS-2000 (for ownership information), and the DART (for audit hours in annual reports).

In the first, all companies that are listed in KOSPI excluding banking and insurance sectors from the year of 2001 to 2010 are subject to our sample and 6,341 observations are gathered. Our sample begins with the year of 2001, because the audit hour data is required to be disclosed in annual report from 2001. Secondly, we exclude 635 observations that audit hours are missing in annual reports, and the third, we exclude 739 observations that audit hours are reported in daily or weekly basis. ${ }^{9}$ The fourth criteria, we exclude 85 observations that reported audit hours are less than 100 in a year. Because it is regarded that less than 100 audit hours in a year is unrealistic in auditing and an error in disclosure. Also we exclude 1,705 and 460 observations if consecutive prior 3 years of pre-tax income and tax expense is negative, respectively, for the estimation of effective tax rates. Finally, after excluding missing variables from the KIS-VALUE and TS-2000 that affect audit hour determination and corporate tax avoidance, 2,588 observations are selected.

\section{Descriptive Statistics}

Table 1 contains descriptive statistics for our sample. Our measure of corporate tax avoidance, the mean for 'GETR_1Y', 'CETR_1Y' is $25.7 \%$ and $27.8 \%$, and standard deviation is $10.9 \%$ and $25.2 \%$, respectively. For the 'GETR_3Y' and 'CETR_3Y', the mean is $25.9 \%$ and $26.3 \%$, and the standard deviation is $8.1 \%$ and $10.6 \%$, respectively. On average, it indicate that GAAP effective tax rate is lower than CASH effective tax rate in mean values, and 3 years of long-run tax rate is lower than single year of annual tax rate in standard deviation. The mean (median) for 'DD_BTD' is $0.013(0.014)$, and 'BTD' is $0.011(0.007)$. The mean (median) for audit hours is 1,610 (825) and abnormal audit hours is $-0.003(0.025)$. Also, the mean (median) for auditor tenure is 4.594 (4) years. The average scaled total assets of our sample is 26.613 (i.e., 1,756 billion in KRW or 1.5 billion in USD $^{10}$ ), and approximately $65.8 \%$ of our sample is Big 4 auditor. Also, the mean (median) for leverage ratio and ratio of return on assets are $40.1 \%(40.4 \%)$ and $6.4 \%(5.6 \%)$, respectively. To mitigate the influence of outliers on our empirical analyses, the effective tax rates such as 'GETR_1Y', 'CETR_1Y', 'GETR_3Y', and 'CETR_3Y' are winsorized to be between 0 and 1 . We also winsorize variables used in our analysis except for dummy style at the $1^{\text {st }}$ and $99^{\text {th }}$ percentiles.

\footnotetext{
${ }^{8}$ In case of cash effective tax rates (i.e., 'CETR_1Y' and 'CETR_3Y'), 2,470 firm-years of observations are used in our analysis for the missing cash tax payments data. In this part of Sample, we describe the sample properties on the basis of 'GETR_1Y' which has larger number of observations.

${ }^{9}$ In the early stage of implementation, the disclosures of audit hours are different in formats (e.g., audit hours, audit days, and audit weeks) and audit hour basis is most typical type of disclosure. We exclude the possibility that translating audit days and audit weeks into audit hours on a uniform standard (e.g., an eight-hour day or five-day week) because it is hard to capture the auditor's additional efforts such as abnormal audit hours.

${ }^{10}$ The base rate of KRW/USD is applied to 1,138.9 KRW to 1 USD on December 31, 2010.
} 
Table 1. Descriptive statistics

\begin{tabular}{|c|c|c|c|c|c|c|}
\hline Variable & $\mathbf{N}$ & Mean & Std.Dev & $5 \%$ & Median & $95 \%$ \\
\hline \multicolumn{7}{|c|}{ Panel A: Tax Avoidance ${ }_{1 \sim 6}$} \\
\hline (1) GETR_1Y & 2,588 & 0.257 & 0.109 & 0.076 & 0.257 & 0.445 \\
\hline (2) CETR_1Y & 2,470 & 0.278 & 0.252 & 0.083 & 0.252 & 0.582 \\
\hline (3) GETR_3Y & 2,588 & 0.259 & 0.081 & 0.121 & 0.264 & 0.375 \\
\hline (4) CETR_3Y & 2,470 & 0.263 & 0.106 & 0.104 & 0.260 & 0.434 \\
\hline (5) DD_BTD & 2,588 & 0.013 & 0.054 & -0.072 & 0.014 & 0.100 \\
\hline (6) BTD & 2,588 & 0.011 & 0.041 & -0.054 & 0.007 & 0.091 \\
\hline \multicolumn{7}{|c|}{ Panel B: Auditor Variable } \\
\hline LN_Audit Hours & 2,588 & 6.844 & 0.876 & 5.662 & 6.715 & 8.423 \\
\hline Actual audit hours & 2,588 & 1,610 & 3,386 & 288 & 825 & 4,550 \\
\hline AB Audit Hour & 2,588 & -0.003 & 0.496 & -0.781 & 0.025 & 0.736 \\
\hline \multicolumn{7}{|c|}{ Panel C: Control Variable } \\
\hline SIZE & 2,588 & 26.613 & 1.497 & 24.738 & 26.276 & 29.733 \\
\hline ADT & 2,588 & 0.658 & 0.474 & 0.000 & 1.000 & 1.000 \\
\hline $\mathrm{CON}$ & 2,588 & 0.647 & 0.478 & 0.000 & 1.000 & 1.000 \\
\hline INVREC & 2,588 & 0.287 & 0.147 & 0.063 & 0.277 & 0.550 \\
\hline EXPR & 2,588 & 0.237 & 0.282 & 0.000 & 0.092 & 0.808 \\
\hline ISSUE & 2,588 & 0.004 & 0.022 & 0.000 & 0.000 & 0.028 \\
\hline LIQ & 2,588 & 2.051 & 1.522 & 0.672 & 1.543 & 5.140 \\
\hline LEV & 2,588 & 0.401 & 0.168 & 0.137 & 0.404 & 0.677 \\
\hline AOP & 2,588 & 0.001 & 0.028 & 0.000 & 0.000 & 0.000 \\
\hline ROA & 2,588 & 0.064 & 0.044 & 0.008 & 0.056 & 0.145 \\
\hline LOSS & 2,588 & 0.003 & 0.059 & 0.000 & 0.000 & 0.000 \\
\hline GRW & 2,588 & 0.096 & 0.196 & -0.158 & 0.079 & 0.409 \\
\hline FIRST & 2,588 & 0.099 & 0.299 & 0.000 & 0.000 & 1.000 \\
\hline OWN & 2,588 & 0.420 & 0.165 & 0.156 & 0.419 & 0.699 \\
\hline FOR & 2,588 & 0.137 & 0.171 & 0.000 & 0.060 & 0.490 \\
\hline
\end{tabular}

We winsorize the variables used in our analysis at the $1^{\text {st }}$ and $99^{\text {th }}$ percentiles except for indicator variables. Negative numerators and denominators are deleted and effective tax rates are winsorized to be between 0 and 1 for CTA measurements.

\section{Definitions of Variables}

GETR_IY = GAAP effective tax rates for 1 year, tax expense of current year divided by pre-tax income of current year;

CETR_ $1 Y=$ CASH effective tax rates for 1 year, cash taxes payment of current year divided by pre-tax income of current year;

GETR_3Y= GAAP effective tax rates for 3 years, sum of tax expenses for three years divided by sum of pre-tax incomes for three years;

CETR_3Y $=$ CASH effective tax rates for 3 years, sum of cash taxes payments for three years divided by sum of pretax incomes for three years;

$D D \_B T D=$ tax avoidance measurement of Desai and Dharmapala (2006), residuals by regressing book-tax differences on total accruals,;

$B T D=$ book-tax differences, calculated as pre-tax income less estimated taxable income scaled by lagged value of total assets;

$L N \_$Audit Hours $=$natural $\log$ of actual audit hours;

Actual audit hours = yearly actual audit hours; 
AB_Audit Hours $=$ differences between actual audit hours and estimated normal audit hours, residuals of audit hours determination model;

and the definition of other variables can be referred to the Eq. (1).

\section{Pearson Correlation}

Table 2 represents the Pearson correlation statistics among the dependent variables and major independent variables which are used for examining the $\mathrm{H}_{1-1}$ and $\mathrm{H}_{1-2}$. As predicted, negative correlations are found between the actual audit hour variable (LN_HOUR) and 'GETR_1Y' (correlation coefficient $=-0.03$, p-value $=0.16$ ), 'CETR_1Y' (correlation coefficient $=-0.08, p$-value $=0.00$ ), 'GETR_3Y' (correlation coefficient $=-0.03$, $p$-value $=0.10$ ), and 'CETR_3Y' (correlation coefficient $=-0.11, \mathrm{p}$-value $=0.00$ ), and also it is positively correlated with 'DD_BTD' (correlation coefficient $=0.13, \mathrm{p}$-value $=0.00$ ), and 'BTD' (correlation coefficient $=0.07, \mathrm{p}$-value $=0.00$ ). The correlation coefficients between abnormal audit hour (AB_HOUR) and six CTA measurements show similar pattern to that of the actual audit hour variable. According to the $\mathrm{H}_{1-1}$ and $\mathrm{H}_{1-2}$, the univariate results suggest that the auditors devote more actual audit hours and abnormal audit hours when they perceive the degree of CTA of client firms as high.

\begin{tabular}{|c|c|c|c|c|c|c|c|c|}
\hline Variable & $\begin{array}{c}\text { LN }_{-} \\
\text {HOUR }\end{array}$ & $\begin{array}{c}\text { AB }_{-} \\
\text {HOUR }\end{array}$ & $\begin{array}{c}\text { GETR } \\
\_1 Y\end{array}$ & $\begin{array}{c}\text { CETR } \\
\_1 Y\end{array}$ & $\begin{array}{c}\text { GETR } \\
\text { _3Y }\end{array}$ & $\begin{array}{c}\text { CETR } \\
\text { 3Y }\end{array}$ & $\begin{array}{l}\text { DD } \\
\text { BTD }\end{array}$ & BTD \\
\hline \multirow{2}{*}{$\begin{array}{l}\mathrm{AB} \\
\text { HOUR }\end{array}$} & 0.56 & & & & & & & \\
\hline & $(0.00)$ & & & & & & & \\
\hline \multirow{2}{*}{$\begin{array}{l}\text { GETR } \\
\_1 Y\end{array}$} & -0.03 & -0.06 & & & & & & \\
\hline & $(0.16)$ & $(0.00)$ & & & & & & \\
\hline \multirow{2}{*}{$\begin{array}{l}\text { CETR } \\
\text { _1Y }\end{array}$} & -0.08 & -0.05 & 0.54 & & & & & \\
\hline & $(0.00)$ & $(0.02)$ & $(0.00)$ & & & & & \\
\hline \multirow{2}{*}{$\begin{array}{l}\text { GETR } \\
-3 Y\end{array}$} & -0.03 & -0.07 & 0.75 & 0.41 & & & & \\
\hline & $(0.10)$ & $(0.00)$ & $(0.00)$ & $(0.00)$ & & & & \\
\hline \multirow{2}{*}{$\begin{array}{l}\text { CETR } \\
-3 Y\end{array}$} & -0.11 & -0.06 & 0.49 & 0.67 & 0.62 & & & \\
\hline & $(0.00)$ & $(0.00)$ & $(0.00)$ & $(0.00)$ & $(0.00)$ & & & \\
\hline \multirow{2}{*}{$\begin{array}{l}\mathrm{DD}_{-} \\
\mathrm{BTD}\end{array}$} & 0.13 & 0.06 & -0.35 & -0.41 & -0.33 & -0.38 & & \\
\hline & $(0.00)$ & $(0.00)$ & $(0.00)$ & $(0.00)$ & $(0.00)$ & $(0.00)$ & & \\
\hline \multirow{2}{*}{ BTD } & 0.07 & 0.04 & -0.42 & -0.47 & -0.40 & -0.44 & 0.82 & \\
\hline & $(0.00)$ & $(0.09)$ & $(0.00)$ & $(0.00)$ & $(0.00)$ & $(0.00)$ & $(0.00)$ & \\
\hline
\end{tabular}

The definition of variables can be referred to the Table 1 .

\section{EMPIRICAL RESULTS}

The purpose of our two hypotheses is to examine whether the CTA is positively associated with the actual audit hours and abnormal audit hours. Panel A of Table 3 represents the regressions of actual audit hours on six CTA measurements and control variables that affect the determination of audit hours $\left(\mathrm{H}_{1-1}\right)$. With respect to the effective tax rates, we find negative associations between the actual audit hours and 'GETR_1Y' (coefficient=-0.197, $t$-value=2.11), 'CETR_1Y' (coefficient $=-0.140$, t-value=-2.15), 'GETR_3Y' (coefficient $=-0.330$, $t$-value $=-2.68$ ), and 'CETR_3Y' (coefficient $=-0.240$, t-value $=-2.37$ ). Also we find positive associations between the actual audit hours and 'DD_BTD' (coefficient=0.498, t-value=3.64) and 'BTD' (coefficient $=0.421, \mathrm{t}-\mathrm{value}=2.48$ ). The result shows that the actual audit hours are increasing with the level of corporate tax avoidance, and it supports the direction of $\mathrm{H}_{1-1}$.

Since estimation of abnormal audit hours is required prior to investigating the $\mathrm{H}_{1-2}$, Panel B of Table 3 represents the regression results of abnormal audit hours. The abnormal audit hours are derived as residuals by regressing the actual audit hours of KOSPI from 2001 to 2010 on the factors that affect the determination of audit hours. Using 4,660 actual audit hours observation, the result reports that the model of normal audit hour estimation explains about 65.51 percent of the variation in total audit hours. 
Panel C of Table 3 represents the regressions of abnormal audit hours on six CTA measurements and control variables. With respect to the effective tax rates, we find negative associations between the abnormal audit hours and 'GETR_1Y' (coefficient=-0.196, t-value=-2.09), 'CETR_1Y' (coefficient=-0.139, t-value=-2.13), 'GETR_3Y' (coefficient=-0.330, $\mathrm{t}$-value $=-2.68$ ), and 'CETR_3Y' (coefficient=-0.238, $\mathrm{t}$-value=-2.36). Also, we find positive relations between the abnormal audit hours and 'DD_BTD' (coefficient $=0.501$, t-value=3.65) and 'BTD' (coefficient $=0.423$, $\mathrm{t}$-value $=-2.49$ ). The results show that the abnormal audit hours are increasing with the level of corporate tax avoidance, corroborating the $\mathrm{H}_{1-2}$. Taken together with the results in Table 3, these findings imply that in response to increased audit risk from CTA, the auditors increase actual audit hours or devote more audit hours than normal level to achieve a given level of audit risk.

Table 3. Main results

Panel A. Results of $\mathrm{H}_{1-1}$

Dependent variable $=$ actual audit hours ${ }_{t}$

\begin{tabular}{|c|c|c|c|c|c|c|}
\hline \multirow{2}{*}{$\begin{array}{l}T A V_{1 \sim 6, t}= \\
\text { Variable }\end{array}$} & \multicolumn{2}{|c|}{ (1) GETR_1Y $Y_{t}$} & \multicolumn{2}{|c|}{ (2) CETR_1Y ${ }_{t}$} & \multicolumn{2}{|c|}{ (3) GETR_3Y $Y_{t}$} \\
\hline & Estimate & t-statistic & Estimate & t-statistic & Estimate & t-statistic \\
\hline Intercept & -3.779 & $-12.32^{* * *}$ & -3.889 & $-12.28^{* * * *}$ & -3.756 & $-12.24^{* * *}$ \\
\hline$T A V_{1 \sim 6, t}$ & -0.197 & $-2.11^{* * *}$ & -0.140 & $-2.15^{* *}$ & -0.330 & $-2.68^{* * * *}$ \\
\hline$S I Z E_{t}$ & 0.398 & $41.35^{* * *}$ & 0.401 & $40.26^{* * *}$ & 0.399 & $41.40^{* * *}$ \\
\hline$A D T_{t}$ & 0.273 & $12.52^{* * *}$ & 0.272 & $12.21^{* * * *}$ & 0.272 & $12.47^{* * * *}$ \\
\hline $\mathrm{CON}_{t}$ & 0.066 & $2.81^{* * *}$ & 0.053 & $2.23^{* *}$ & 0.065 & $2.78^{* * * *}$ \\
\hline$I N V R E C_{t}$ & 0.225 & $2.74^{* * * *}$ & 0.208 & $2.48^{* *}$ & 0.234 & $2.85^{* * *}$ \\
\hline$E X P R_{t}$ & 0.039 & 1.03 & 0.039 & 1.01 & 0.035 & 0.91 \\
\hline$I S S U E_{t}$ & 0.968 & $2.11^{* * *}$ & 0.897 & 1.92 & 0.989 & $2.16^{* *}$ \\
\hline$L I Q_{t}$ & -0.048 & $-5.35^{* * *}$ & -0.044 & $-4.65^{* * * *}$ & -0.049 & $-5.48^{* * *}$ \\
\hline$L E V_{t}$ & -0.088 & -0.96 & -0.042 & -0.42 & -0.099 & -1.07 \\
\hline$A O P_{t-1}$ & -0.041 & -0.12 & -0.072 & -0.21 & -0.037 & -0.11 \\
\hline$R O A_{t}$ & 0.217 & 0.83 & 0.111 & 0.40 & 0.219 & 0.85 \\
\hline$L_{O S S_{t}}$ & 0.251 & 1.52 & 0.236 & 1.44 & 0.227 & 1.40 \\
\hline$G R W_{t}$ & -0.132 & $-2.52^{* * *}$ & -0.149 & $-2.74^{* * * *}$ & -0.135 & $-2.59^{* * *}$ \\
\hline FIRST $_{t}$ & -0.091 & $-2.75^{* * *}$ & -0.082 & $-2.39^{* * *}$ & -0.091 & $-2.73^{* * *}$ \\
\hline$O W N_{t}$ & -0.280 & $-4.63^{* * * *}$ & -0.279 & $-4.44^{* * * *}$ & -0.284 & $-4.69^{* * * *}$ \\
\hline$F O R_{t}$ & 0.263 & $3.78^{* * *}$ & 0.296 & $4.05^{* * * *}$ & 0.262 & $3.78^{* * * *}$ \\
\hline Year \& Industry & \multicolumn{2}{|c|}{ FIXED } & \multicolumn{2}{|c|}{ FIXED } & \multicolumn{2}{|c|}{ FIXED } \\
\hline $\mathrm{N}$ & \multicolumn{2}{|c|}{2,588} & \multicolumn{2}{|c|}{2,470} & \multicolumn{2}{|c|}{2,588} \\
\hline Max VIF & \multicolumn{2}{|c|}{2.68} & \multicolumn{2}{|c|}{2.90} & \multicolumn{2}{|c|}{2.68} \\
\hline Adjusted-R ${ }^{2}$ & \multicolumn{2}{|c|}{$70.02 \%$} & \multicolumn{2}{|c|}{$70.56 \%$} & \multicolumn{2}{|c|}{$70.05 \%$} \\
\hline
\end{tabular}

(Table 3 continued on next page) 
(Table 3 continued)

\begin{tabular}{|c|c|c|c|c|c|c|}
\hline \multicolumn{7}{|c|}{ Panel A. Results of $\mathrm{H}_{1-1}$ (continued) } \\
\hline \multicolumn{7}{|c|}{ Dependent variable $=$ actual audit hours ${ }_{t}$} \\
\hline$T A V_{1 \sim 6, i}=$ & \multicolumn{2}{|c|}{ (4) CETR_3Y } & \multicolumn{2}{|c|}{ (5) DD_BTD } & \multicolumn{2}{|c|}{ (6) BTD BT $_{t}$} \\
\hline Variable & Estimate & t-statistic & Estimate & t-statistic & Estimate & t-statistic \\
\hline Intercept & -3.866 & $-12.19^{* * * *}$ & -3.781 & $-12.36^{* * * *}$ & -3.768 & $-12.28^{* * * *}$ \\
\hline$T A V_{1 \sim 6, t}$ & -0.240 & $-2.37^{* *}$ & 0.498 & $3.64^{* * * *}$ & 0.421 & $2.48^{* * *}$ \\
\hline$S I Z E_{t}$ & 0.402 & $40.31^{* * *}$ & 0.397 & $41.38^{* * *}$ & 0.397 & $41.30^{* * *}$ \\
\hline$A D T_{t}$ & 0.271 & $12.18^{* * * *}$ & 0.271 & $12.44^{* * *}$ & 0.272 & $12.46^{* * * *}$ \\
\hline$C O N_{t}$ & 0.053 & $2.23^{* *}$ & 0.064 & $2.74^{* * * *}$ & 0.063 & $2.69^{* * * *}$ \\
\hline${ }^{\prime N V R E C} C_{t}$ & 0.221 & $2.61^{* * * *}$ & 0.214 & $2.63^{* * * *}$ & 0.196 & $2.41^{* * *}$ \\
\hline$E X P R_{t}$ & 0.030 & 0.78 & 0.038 & 1.01 & 0.039 & 1.02 \\
\hline$I S S U E_{t}$ & 0.865 & 1.85 & 1.033 & $2.26^{* *}$ & 1.001 & $2.18^{* *}$ \\
\hline$L I Q_{t}$ & -0.044 & $-4.62^{* * * *}$ & -0.046 & $-5.22^{* * * *}$ & -0.047 & $-5.25^{* * * *}$ \\
\hline$L E V_{t}$ & -0.045 & -0.46 & -0.082 & -0.89 & -0.080 & -0.87 \\
\hline$A O P_{t-1}$ & -0.049 & -0.14 & -0.044 & -0.13 & -0.047 & -0.14 \\
\hline$R O A_{t}$ & 0.143 & 0.53 & 0.083 & 0.31 & 0.089 & 0.32 \\
\hline $\operatorname{LOSS}_{t}$ & 0.209 & 1.29 & 0.182 & 1.13 & 0.181 & 1.12 \\
\hline$G R W_{t}$ & -0.150 & $-2.76^{* * * *}$ & -0.134 & $-2.57^{* * *}$ & -0.135 & $-2.59^{* * * *}$ \\
\hline FIRST $_{t}$ & -0.082 & $-2.41^{* * * *}$ & -0.090 & $-2.73^{* * *}$ & -0.090 & $-2.72^{* * * *}$ \\
\hline$O W N_{t}$ & -0.286 & $-4.55^{* * * *}$ & -0.282 & $-4.67^{* * *}$ & -0.285 & $-4.70^{* * *}$ \\
\hline$F O R_{t}$ & 0.296 & $4.06^{* * * *}$ & 0.252 & $3.64^{* * * *}$ & 0.261 & $3.76^{* * * *}$ \\
\hline Year \& Industry & \multicolumn{2}{|c|}{ FIXED } & \multicolumn{2}{|c|}{ FIXED } & \multicolumn{2}{|c|}{ FIXED } \\
\hline $\mathrm{N}$ & \multicolumn{2}{|c|}{2,470} & \multicolumn{2}{|c|}{2,588} & \multicolumn{2}{|c|}{2,588} \\
\hline Max VIF & \multicolumn{2}{|c|}{2.90} & \multicolumn{2}{|c|}{2.68} & \multicolumn{2}{|c|}{2.68} \\
\hline Adjusted-R ${ }^{2}$ & \multicolumn{2}{|c|}{$70.57 \%$} & \multicolumn{2}{|c|}{$70.12 \%$} & \multicolumn{2}{|c|}{$70.04 \%$} \\
\hline
\end{tabular}

\begin{tabular}{|c|c|c|}
\hline \multicolumn{3}{|c|}{ Panel B. Estimation of abnormal audit hours } \\
\hline \multicolumn{3}{|c|}{ Dependent variable $=$ Actual audit hours $s_{t}$} \\
\hline Variable & Estimate & t-statistic \\
\hline Intercept & -3.647 & $-15.94^{* * * *}$ \\
\hline$S I Z E_{t}$ & 0.385 & $51.70^{* * *}$ \\
\hline$A D T_{t}$ & 0.302 & $17.33^{* * * *}$ \\
\hline$C O N_{t}$ & 0.070 & $3.77^{* * *}$ \\
\hline$I N V R E C_{t}$ & 0.084 & 1.35 \\
\hline$E X P R_{t}$ & 0.065 & $2.32^{* *}$ \\
\hline$I S S U E_{t}$ & 1.488 & $3.22^{* *}$ \\
\hline$L I Q_{t}$ & -0.026 & $-3.62^{* * *}$ \\
\hline$L E V_{t}$ & 0.084 & 1.36 \\
\hline$A O P_{t-1}$ & -0.198 & $-1.85^{*}$ \\
\hline$R O A_{t}$ & -0.028 & -0.36 \\
\hline$L_{O S S}$ & 0.050 & $1.89^{* *}$ \\
\hline$G R W_{t}$ & -0.049 & $-1.98^{* *}$ \\
\hline FIRST $_{t}$ & -0.068 & $-2.57^{* * *}$ \\
\hline$O W N_{t}$ & -0.382 & $-8.06^{* * * *}$ \\
\hline$F O R_{t}$ & 0.241 & $4.51^{* * * *}$ \\
\hline YEAR \& INDUSTRY & & \\
\hline $\mathrm{N}$ & & \\
\hline Max VIF & & \\
\hline Adjusted- $\mathrm{R}^{2}$ & & \\
\hline
\end{tabular}

(Table 3 continued on next page) 
(Table 3 continued)

\begin{tabular}{|c|c|c|c|c|c|c|}
\hline \multicolumn{7}{|c|}{ Panel C. Results of $\mathrm{H}_{1-2}$} \\
\hline \multicolumn{7}{|c|}{ Dependent variable $=$ actual audit hours $s_{t}$} \\
\hline$T A V_{1 \sim 6, t}=$ & \multicolumn{2}{|c|}{ (1) GETR_1Y $Y_{t}$} & \multicolumn{2}{|c|}{ (2) CETR_1Y $Y_{t}$} & \multicolumn{2}{|c|}{ (3) GETR_3Y $Y_{t}$} \\
\hline Variable & Estimate & t-statistic & Estimate & t-statistic & Estimate & t-statistic \\
\hline Intercept & 0.132 & 0.43 & -3.889 & $-12.28^{* * * *}$ & 0.154 & 0.50 \\
\hline$T A V_{l \sim 6, t}$ & -0.196 & $-2.09^{* *}$ & -0.140 & $-2.15^{* *}$ & -0.330 & $-2.68^{* * *}$ \\
\hline$S I Z E_{t}$ & 0.010 & 0.99 & 0.401 & $40.26^{* * *}$ & 0.010 & 1.08 \\
\hline$A D T_{t}$ & -0.024 & -1.11 & 0.272 & $12.21^{* * * *}$ & -0.025 & -1.16 \\
\hline$C O N_{t}$ & -0.029 & -1.22 & 0.053 & $2.23^{* *}$ & -0.029 & -1.25 \\
\hline$I_{N V R E C_{t}}$ & 0.067 & 0.81 & 0.208 & $2.48^{* *}$ & 0.076 & 0.93 \\
\hline$E X P R_{t}$ & -0.028 & -0.74 & 0.039 & 1.01 & -0.033 & -0.85 \\
\hline$I S S U E_{t}$ & 0.134 & 0.29 & 0.897 & 1.92 & 0.155 & 0.34 \\
\hline$L I Q_{t}$ & -0.018 & $-2.07^{* *}$ & -0.044 & $-4.65^{* * * *}$ & -0.020 & $-2.21^{* *}$ \\
\hline$L E V_{t}$ & -0.083 & -0.91 & -0.042 & -0.42 & -0.094 & -1.02 \\
\hline$A O P_{t-1}$ & 0.355 & 1.03 & -0.072 & -0.21 & 0.359 & 1.04 \\
\hline$R O A_{t}$ & 0.317 & 1.21 & 0.111 & 0.40 & 0.318 & 1.23 \\
\hline$L_{O S S_{t}}$ & 0.206 & 1.25 & 0.236 & 1.44 & 0.183 & 1.13 \\
\hline$G R W_{t}$ & -0.122 & $-2.33^{* *}$ & -0.149 & $-2.74^{* * * *}$ & -0.125 & $-2.40^{* *}$ \\
\hline FIRST $_{t}$ & -0.039 & -1.19 & -0.082 & $-2.39^{* * *}$ & -0.039 & -1.17 \\
\hline$O W N_{t}$ & 0.084 & 1.39 & -0.279 & $-4.44^{* * * *}$ & 0.081 & 1.34 \\
\hline$F O R_{t}$ & 0.002 & 0.02 & 0.296 & $4.05^{* * *}$ & 0.001 & 0.02 \\
\hline Year \& Industry & \multicolumn{2}{|c|}{ FIXED } & \multicolumn{2}{|c|}{ FIXED } & \multicolumn{2}{|c|}{ FIXED } \\
\hline $\mathrm{N}$ & \multicolumn{2}{|c|}{2,588} & \multicolumn{2}{|c|}{2,470} & \multicolumn{2}{|c|}{2,588} \\
\hline Max VIF & \multicolumn{2}{|c|}{2.68} & \multicolumn{2}{|c|}{2.90} & \multicolumn{2}{|c|}{2.68} \\
\hline Adjusted- $\mathrm{R}^{2}$ & \multicolumn{2}{|c|}{$6.39 \%$} & \multicolumn{2}{|c|}{$6.23 \%$} & \multicolumn{2}{|c|}{$6.49 \%$} \\
\hline
\end{tabular}

\begin{tabular}{|c|c|c|c|c|c|c|}
\hline \multicolumn{7}{|c|}{ Panel C. Results of $\mathrm{H}_{1-2}$ (continued) } \\
\hline \multicolumn{7}{|c|}{ Dependent variable $=$ actual audit hours ${ }_{t}$} \\
\hline$T A V_{1 \sim 6, t}=$ & \multicolumn{2}{|c|}{ (4) CETR_3Y $Y_{t}$} & \multicolumn{2}{|c|}{ (5) DD_BTD ${ }_{t}$} & \multicolumn{2}{|c|}{ (6) BTD BT $_{t}$} \\
\hline Variable & Estimate & t-statistic & Estimate & t-statistic & Estimate & t-statistic \\
\hline Intercept & 0.044 & 0.14 & 0.130 & 0.42 & 0.143 & 0.47 \\
\hline$T A V_{1 \sim 6, t}$ & -0.238 & $-2.36^{* *}$ & 0.501 & $3.65^{* * *}$ & 0.423 & $2.49^{* *}$ \\
\hline$S I Z E_{t}$ & 0.013 & 1.33 & 0.008 & 0.88 & 0.008 & 0.86 \\
\hline$A D T_{t}$ & -0.026 & -1.15 & -0.026 & -1.20 & -0.025 & -1.16 \\
\hline $\mathrm{CON}_{t}$ & -0.041 & $-1.71^{*}$ & -0.030 & -1.30 & -0.031 & -1.34 \\
\hline$I N V R E C_{t}$ & 0.063 & 0.74 & 0.056 & 0.69 & 0.039 & 0.47 \\
\hline$E X P R_{t}$ & -0.037 & -0.94 & -0.029 & -0.77 & -0.029 & -0.75 \\
\hline$I S S U E_{t}$ & 0.037 & 0.08 & 0.199 & 0.44 & 0.167 & 0.36 \\
\hline$L I Q_{t}$ & -0.015 & -1.54 & -0.017 & $-1.94^{*}$ & -0.018 & $-1.98^{* *}$ \\
\hline$L E V_{t}$ & -0.040 & -0.41 & -0.077 & -0.84 & -0.075 & -0.82 \\
\hline$A O P_{t-1}$ & 0.347 & 1.01 & 0.352 & 1.02 & 0.349 & 1.01 \\
\hline$R O A_{t}$ & 0.243 & 0.90 & 0.180 & 0.68 & 0.186 & 0.68 \\
\hline $\operatorname{LOSS}_{t}$ & 0.165 & 1.02 & 0.138 & 0.86 & 0.137 & 0.85 \\
\hline$G R W_{t}$ & -0.140 & $-2.58^{* * *}$ & -0.124 & $-2.38^{* *}$ & -0.126 & $-2.40^{* *}$ \\
\hline FIRST $_{t}$ & -0.031 & -0.89 & -0.039 & -1.17 & -0.038 & -1.16 \\
\hline$O W N_{t}$ & 0.078 & 1.25 & 0.082 & 1.36 & 0.080 & 1.32 \\
\hline$F O R_{t}$ & 0.035 & 0.48 & -0.009 & -0.13 & 0.000 & 0.00 \\
\hline Year \& Industry & \multicolumn{2}{|c|}{ FIXED } & \multicolumn{2}{|c|}{ FIXED } & \multicolumn{2}{|c|}{ FIXED } \\
\hline $\mathrm{N}$ & \multicolumn{2}{|c|}{2,470} & \multicolumn{2}{|c|}{2,588} & \multicolumn{2}{|c|}{2,588} \\
\hline Max VIF & \multicolumn{2}{|c|}{2.90} & \multicolumn{2}{|c|}{2.68} & \multicolumn{2}{|c|}{2.68} \\
\hline Adjusted- $\mathrm{R}^{2}$ & \multicolumn{2}{|c|}{$6.27 \%$} & \multicolumn{2}{|c|}{$6.71 \%$} & \multicolumn{2}{|c|}{$6.45 \%$} \\
\hline
\end{tabular}

***, **, * Indicate significance at $0.01,0.05$, and 0.10 levels, respectively. The definition of variables can be referred to the Table 1. 


\section{Additional Analyses}

\section{Common Factor of Corporate Tax Avoidance Measurements}

In our analyses, we adopt multiple measurements of CTA. Each method is effective to measure the tendency of CTA and the approach has its own strength and weakness. For the robustness of our results, we present the results of factor analysis by extracting the common factor from multiple measurements. Technically, we multiply four effective tax rates (i.e., GETR_1Y, CETR_1Y, GETR_3Y, GETR_3Y) by '-1' for identical direction in interpretation with 'DD_BTD' and 'BTD'. Thus, it is expected that the degree of CTA is positively associated with the common factor. The first and second column of Table 4 reports the factor analyses of the $\mathrm{H}_{1-1}$ and $\mathrm{H}_{1-2}$. The common factor of six CTA measurements $\left(\right.$ TAV $\left.V_{\text {FACTOR }}\right)$ is positively associated with ' $L N \_$Audit Hour ${ }_{t}$ ' (coefficient=0.048, t-value=3.80) and 'AB_Audit Hour' ${ }_{t}$ (coefficient=0.048, t-value=3.79). The results show that the actual and abnormal audit hours are increasing with the level of corporate tax avoidance which is consistent with the main results of Table 3.

Table 4. Factor analyses

\begin{tabular}{|c|c|c|c|c|}
\hline \multirow{2}{*}{ Variable } & \multicolumn{2}{|c|}{ (1) LN_Audit Hour / TAV $_{\text {FACTOR }}$} & \multicolumn{2}{|c|}{ (2) AB_Audit Hour ${ }_{t} /$ TAV $_{\text {FACTOR }}$} \\
\hline & Estimate & t-statistic & Estimate & t-statistic \\
\hline Intercept & -3.921 & $-11.50^{* * *}$ & -0.009 & -0.03 \\
\hline$T A V_{F A C T O R, t}$ & 0.048 & $3.80^{* * *}$ & 0.048 & $3.79^{* * *}$ \\
\hline Other control variables & \multicolumn{2}{|c|}{ CONTROLLED } & \multicolumn{2}{|c|}{ CONTROLLED } \\
\hline Year \& Industry & \multicolumn{2}{|c|}{ FIXED } & \multicolumn{2}{|c|}{ FIXED } \\
\hline $\mathrm{N}$ & \multicolumn{2}{|c|}{2,470} & \multicolumn{2}{|c|}{2,470} \\
\hline Max VIF & \multicolumn{2}{|c|}{2.90} & \multicolumn{2}{|c|}{2.90} \\
\hline Adjusted- $\mathrm{R}^{2}$ & \multicolumn{2}{|c|}{$69.98 \%$} & \multicolumn{2}{|c|}{$7.13 \%$} \\
\hline
\end{tabular}

***,**, * Indicate significance at $0.01,0.05$, and 0.10 levels, respectively.

One Fiscal Year of Time Lag Analysis for $H_{1-1}$ and $H_{1-2}$

In this part, we investigate the auditor's response to prior fiscal year of CTA which can be the supporting evidence of $\mathrm{H}_{1-1}$ and $\mathrm{H}_{1-2}$. Because the experiences in auditing affect auditors' performance (Bonner 1990) and the auditors should review prior working papers for their audit planning (U.S. Auditing Standards Section 312: Audit risk and materiality in conducting an audit), investigating the impact of prior fiscal year of corporate tax avoidance on current level of audit efforts would supply the additional proof regarding the $\mathrm{H}_{1-1}$ and $\mathrm{H}_{1-2}$. Furthermore, the time lag analysis addresses the simultaneous effects between dependent and independent variable. Since the dependent and independent variables are current auditor efforts and current corporate tax avoidance measurements, respectively, in the equation (1) and (7), it cannot exclude the possibility that the main results are affected by the impact of audit hours on CTA. In other words, there is a possibility that the auditors have influence on the clients' tax planning in current year. So we examine the impact of prior fiscal year of CTA on current level of audit efforts to capture the auditor's perception of CTA as a risk factor.

Panel A of Table 5 reports the regressions of current audit hours on prior fiscal year of six CTA measurements. With respect to the effective tax rates, we find negative associations between prior fiscal year of 'GETR_1Y' (coefficient=0.179, t-value=-2.02), 'CETR_1Y' (coefficient=-0.040, t-value=-0.66), 'GETR_3Y' (coefficient=-0.284, t-value=2.36), and 'CETR_3Y' (coefficient=-0.174, t-value=-1.75) and current actual audit hours. Also, we find positive associations between current actual audit hours and prior fiscal year of 'DD_BTD' (coefficient=0.857, $t$-value=2.76) and 'BTD' (coefficient=0.159, t-value=0.98). Regarding the impact of prior fiscal year of CTA on current level of abnormal audit hours, Panel B of Table 5 presents the results and they are similar to that of Panel A. Although the significances of some tax avoidance measurements are below the 10\% level (i.e., 'CETR_1Y' and 'BTD'), the directions are consistent as predicted and the coefficients of factor analyses are at the $1 \%$ level of significance. Thus, these results imply that the auditors perceive the risk factor of CTA and devote more audit efforts to achieve a given level of audit risk. 
Table 5. Additional regression analyses

\begin{tabular}{|c|c|c|c|c|c|c|}
\hline \multicolumn{7}{|c|}{ Panel A. Time lag analysis for $\mathrm{H}_{1-1}$} \\
\hline \multicolumn{7}{|c|}{ Dependent variable $=$ actual audit hours ${ }_{t}$} \\
\hline \multirow{2}{*}{$\begin{array}{l}T A V_{1 \sim 6, t}= \\
\text { Variable }\end{array}$} & \multicolumn{2}{|c|}{ (1) GETR_1Y $Y_{t-1}$} & \multicolumn{2}{|c|}{ (2) CETR_1YY } & \multicolumn{2}{|c|}{ (3) GETR_3Y $Y_{t-1}$} \\
\hline & Estimate & t-statistic & Estimate & t-statistic & Estimate & t-statistic \\
\hline Intercept & -3.958 & $-12.78^{* * *}$ & -4.034 & $-12.77^{* * *}$ & -3.942 & $-12.73^{* * *}$ \\
\hline$T A V_{I \sim 6, t}$ & -0.179 & $-2.02^{* *}$ & -0.040 & -0.66 & -0.284 & $-2.36^{* *}$ \\
\hline $\mathrm{N}$ & \multicolumn{2}{|c|}{2,588} & \multicolumn{2}{|c|}{2,308} & \multicolumn{2}{|c|}{2,588} \\
\hline Max VIF & \multicolumn{2}{|c|}{2.73} & \multicolumn{2}{|c|}{3.01} & \multicolumn{2}{|c|}{2.73} \\
\hline Adjusted-R ${ }^{2}$ & \multicolumn{2}{|c|}{$70.42 \%$} & \multicolumn{2}{|c|}{$72.03 \%$} & \multicolumn{2}{|c|}{$70.44 \%$} \\
\hline Other Control Variables & \multicolumn{6}{|c|}{ CONTROLLED } \\
\hline Year \& Industry & \multicolumn{6}{|c|}{ FIXED } \\
\hline
\end{tabular}

Panel A. continued

Dependent variable $=$ actual audit hours ${ }_{t}$

\begin{tabular}{|c|c|c|c|c|c|c|c|c|}
\hline \multirow{2}{*}{$\begin{array}{l}T A V_{1 \sim 6, t}= \\
\text { Variable }\end{array}$} & \multicolumn{2}{|c|}{ 4) CETR_3Y } & \multicolumn{2}{|c|}{ (5) DD_BTD $t-1$} & \multicolumn{2}{|c|}{ (6) BTD $_{t-1}$} & \multicolumn{2}{|c|}{ (7) TAV FACTOR t-1 } \\
\hline & Estimate & t-statistic & Estimate & t-statistic & Estimate & t-statistic & Estimate & t-statistic \\
\hline Intercept & -3.985 & $-12.59^{* * *}$ & -3.990 & $-12.89^{* * *}$ & -3.968 & $-12.80^{* * *}$ & -3.907 & $-14.45^{* * *}$ \\
\hline$T A V_{l \sim 6, t}$ & -0.174 & $-1.75^{*}$ & 0.857 & $2.76^{* * *}$ & 0.159 & 0.98 & 0.032 & $3.06^{* * *}$ \\
\hline $\mathrm{N}$ & \multicolumn{2}{|c|}{2,308} & \multicolumn{2}{|c|}{2,588} & \multicolumn{2}{|c|}{2,588} & \multicolumn{2}{|c|}{2,588} \\
\hline Max VIF & \multicolumn{2}{|c|}{3.01} & \multicolumn{2}{|c|}{2.70} & \multicolumn{2}{|c|}{2.71} & \multicolumn{2}{|c|}{3.01} \\
\hline Adjusted- $\mathrm{R}^{2}$ & \multicolumn{2}{|c|}{$72.06 \%$} & \multicolumn{2}{|c|}{$70.46 \%$} & \multicolumn{2}{|c|}{$70.38 \%$} & \multicolumn{2}{|c|}{$72.14 \%$} \\
\hline Other Control Variables & \multicolumn{8}{|c|}{ CONTROLLED } \\
\hline Year \& Industry & \multicolumn{8}{|c|}{ FIXED } \\
\hline
\end{tabular}

Panel B. Time lag analysis for $\mathrm{H}_{1-2}$

Dependent variable $=$ actual audit hours ${ }_{t}$

\begin{tabular}{|c|c|c|c|c|c|c|}
\hline \multirow{2}{*}{$\begin{array}{l}T A V_{1 \sim 6, t}= \\
\text { Variable }\end{array}$} & \multicolumn{2}{|c|}{ (1) GETR_1Y $Y_{t-1}$} & \multicolumn{2}{|c|}{ (2) CETR_1Y $Y_{t-1}$} & \multicolumn{2}{|c|}{ (3) GETR_3Y $Y_{t-1}$} \\
\hline & Estimate & t-statistic & Estimate & t-statistic & Estimate & t-statistic \\
\hline Intercept & -0.041 & -0.13 & -0.123 & -0.39 & -0.024 & -0.08 \\
\hline$T A V_{l \sim 6, t}$ & -0.184 & $-2.06^{* *}$ & -0.040 & -0.66 & -0.289 & $-2.41^{* * *}$ \\
\hline $\mathrm{N}$ & \multicolumn{2}{|c|}{2,588} & \multicolumn{2}{|c|}{2,308} & \multicolumn{2}{|c|}{2,588} \\
\hline Max VIF & \multicolumn{2}{|c|}{2.73} & \multicolumn{2}{|c|}{3.01} & \multicolumn{2}{|c|}{2.73} \\
\hline Adjusted-R ${ }^{2}$ & \multicolumn{2}{|c|}{$6.44 \%$} & \multicolumn{2}{|c|}{$5.03 \%$} & \multicolumn{2}{|c|}{$6.49 \%$} \\
\hline Other Control Variables & \multicolumn{6}{|c|}{ CONTROLLED } \\
\hline Year \& Industry & \multicolumn{6}{|c|}{ FIXED } \\
\hline
\end{tabular}

Panel B. continued

Dependent variable $=$ actual audit hours ${ }_{t}$

\begin{tabular}{|c|c|c|c|c|c|c|c|c|}
\hline \multirow{2}{*}{$\begin{array}{l}T A V_{1 \sim 6, t}= \\
\text { Variable }\end{array}$} & \multicolumn{2}{|c|}{ 4) CETR_3Y t-11 } & \multicolumn{2}{|c|}{ (5) DD_BTD ${ }_{t-1}$} & \multicolumn{2}{|c|}{ (6) BTD $t-1$} & \multicolumn{2}{|c|}{ (7) TAV FACTOR t-1 } \\
\hline & Estimate & t-statistic & Estimate & t-statistic & Estimate & t-statistic & Estimate & t-statistic \\
\hline Intercept & -0.074 & -0.23 & -0.044 & -0.14 & -0.051 & -0.16 & -0.159 & -0.59 \\
\hline$T A V_{l \sim 6, t}$ & -0.175 & $-1.76^{*}$ & 0.286 & $2.11^{* *}$ & 0.163 & 1.00 & 0.031 & $3.01^{* * *}$ \\
\hline $\mathrm{N}$ & \multicolumn{2}{|c|}{2,308} & \multicolumn{2}{|c|}{2,588} & \multicolumn{2}{|c|}{2,588} & \multicolumn{2}{|c|}{2,588} \\
\hline Max VIF & \multicolumn{2}{|c|}{3.01} & \multicolumn{2}{|c|}{2.70} & \multicolumn{2}{|c|}{2.71} & \multicolumn{2}{|c|}{3.01} \\
\hline Adjusted-R ${ }^{2}$ & \multicolumn{2}{|c|}{$5.14 \%$} & \multicolumn{2}{|c|}{$6.44 \%$} & \multicolumn{2}{|c|}{$6.32 \%$} & \multicolumn{2}{|c|}{$5.43 \%$} \\
\hline Other Control Variables & \multicolumn{8}{|c|}{ CONTROLLED } \\
\hline Year \& Industry & \multicolumn{8}{|c|}{ FIXED } \\
\hline
\end{tabular}

***, $* *, *$ Indicate significance at $0.01,0.05$, and 0.10 levels, respectively. 


\section{CONCLUSIONS}

The CTA can be expected as a beneficial strategy for shareholder values as it minimizes tax payments to the outside of company. Despite the positive side of CTA, it may involve information asymmetry around the firm and agency conflict between managers and other parties. And the negative aspects of corporate tax avoidance may increase inherent risk and control risk of audit risks. Considering the monitoring role of external auditing, the auditors may respond to increased inherent and control risks which are consequent to CTA and the auditor responses are expected to reflect directly in audit hours.

For this empirical question, this paper tries to verify auditor behavior toward CTA via audit efforts. In particular, we examine the effect of CTA on actual audit hours and abnormal audit hours (i.e., auditor perception of CTA as a risk factor). Using 2,588 firm-year observations from the KOSPI (Korea stock exchange market) in the period 2001-2010, the main results are as following. First, in response to increased audit risk from CTA, auditors increase the actual audit hours or devote more audit hours than normal to achieve a given level of audit risk.

This study contributes to the literature and auditing practices by extending the auditing and tax literature on the examination of auditor behavior toward CTA and by implying the firms' CTA behavior is one of the audit risk factors that affect audit planning, respectively. But we cannot exclude the possibility that omitted variables might affect to our main results.

\section{ACKNOWLEDGEMENT}

This work was supported by the Ministry of Education of the Republic of Korea and the National Research Foundation of Korea (NRF-2015S1A5A8016744).

\section{AUTHOR BIOGRAPHY}

Seong Ho Bae is an assistant professor of accounting at the Kyungpook National University Business School, South Korea. His research focuses on the auditor's behaviors, current tax issues and analysts' forecasts properties. Professor Bae is a licensed CPA in South Korea. (E-mail: shobae@knu.ac.kr)

\section{REFERENCES}

Balakrishnan K., J. Blouin., W. Guay. 2011. Does tax aggressiveness reduce financial reporting transparency? Working paper. Bell, T. B., M, E. Peecher., I. Solomon. 2006. The $21^{\text {st }}$ century public company audit: Conceptual elements of KPMG's global audit methodology. KPMG LLP.

Bonner, S. E. 1990. Experience effects in auditing: The role of task-specific knowledge. The Accounting Review 65(1): $72-92$.

Caramanis, C., C. Lennox. 2008. Audit effort and earnings management. Journal of Accounting and Economics 45: 116-138.

Chen, K. P., Chu, C. 2005. Internal control vs. external manipulation: A model of corporate income tax evasion. RAND Journal of Economics 36: 151-164.

Chen, S., Chen, X., Cheng, Q., Shevlin, T. 2010. Are family forms more tax aggressive than non-family firms? Journal of Financial Economics 95: 41-61.

Choi, J. H., J. B. Kim, Y. Zhang. 2010. Do abnormally high audit fees impair audit quality. Auditing: A Journal of Practice and Theory 29(2): 73-97.

Davis, L., D. Ricchiute, G. Trompeter. 1993. Audit effort, audit fees, and the provision of non-audit services to audit clients. The Accounting Review 68(1): 135-150.

Desai, M. 2005. The degradation of reported corporate profits. Journal of Economic Perspectives 19(4): 171-192.

Desai, M., Dharmapala, D. 2006. Corporate tax avoidance and high-powered incentives. Journal of Financial Economics 79 : 145-179.

Desai, M., Dyck, I., Zingales, L. 2007b. Theft and taxes. Journal of Financial Economics 84: 591-623.

Donohoe. M. P. and W. R. Knechel. 2014. Does corporate tax aggressiveness influence audit pricing? Contemporary Accounting Research 31(1): 284-308.

Dyreng, S. D., Hanlon, M., Maydew, E. L. 2008. Long-run corporate tax avoidance. The Accounting Review 83(1): 61-82.

Dyreng, S. D., Hanlon, M., Maydew, E. L. 2010. The effects of Executives on Corporate Tax Avoidance. The Accounting Journal 85(4): 1163-1189.

Dhaliwal, D. S., Huang, S. X., Moser, W., Pereira, R. 2011. Corporate tax avoidance and the level and valuation of firm cash 
holdings. Working paper.

Frank, M. M., Lynch, L.J., Rego, S. O. 2009. Tax reporting aggressiveness and its relation to aggressive financial reporting. The Accounting Review 84: 467-496.

Hanlon, M., Heitzman, S. 2010. A review of tax research. Journal of Accounting and Economics 50: 127-178.

Hope, O. K., T. Kang., W. B. Thomas, Y. K. Yoo. 2009. Impact of excess auditor remuneration on the cost of equity capital around the world. Journal of Accounting, Auditing and Finance 24(2): 177-210.

Hribar, P., D. W. Collins. 2002. Errors in estimating accruals: Implications for empirical research. Journal of Accounting Research 40(1): 105-134.

Lennox, C. 2005. Management ownership and audit firm size. Contemporary Accounting Research 22(1): 205-227.

Jensen, M. C., W. H. Meckling. 1976. Theory of the firm: Managerial behavior, agency costs and ownership structure. Journal of Financial Economics 3(4): 305-360.

Kim, J. B., Y. Li., L. Zhang. 2011. Corporate tax avoidance and stock price crash risk: Firm-level analysis. Journal of Financial Economies 100: 639-662.

Kothari, S. P., A. J. Leone, C. E. Wasley. 2005. Performance matched discretionary accrual measures. Journal of Accounting and Economics 39: 163-197.

Manzon, G., Plesko, G. 2002. The relation between financial and tax reporting measures of income. Tax Law Review 55: $175-$ 214.

McGuire, S. T., T. C. Omer, D Wang. 2012. Tax avoidance: Does tax-specific industry expertise make a difference? The Accounting Review 87(3): 975-1003.

Mills, L. 1998. Book-tax differences and internal revenue service adjustments. Journal of Accounting Research 36(2): $343-356$.

Niemi, L. 2002. Do firms pay for audit risk? Evidence on risk premiums in audit fees after direct control for audit effort. International Journal of Auditing 6: 37-51.

O'Keefe, T., D. Simunic, M. Stein. 1994. The production of audit service: Evidence from a major public accounting firm. Journal of Accounting Research 32(Autumn): 241-261.

Palmrose, Z. V. 1988. An analysis of auditor litigation and audit service quality. The Accounting Review, 63(1): 55-73.

Palmrose, Z. V. 1989. The relations of audit contract type to audit fees and hours. The Accounting Review, 64(3): $488-499$.

Pittman, J. A., S. Fortin. 2004. Auditor choice and the cost of debt capital for newly public firms. Journal of Accounting and Economics 37: 113-136.

Richardson, G., Lanis, R. 2007. Determinants of the variability in corporate effective tax rates and tax reform: Evidence from Australia. Journal of Accounting and Public Policy 26: 689-704.

Rego, S. O. 2003. Tax-Avoidance activities of U.S. multinational corporations. Contemporary Accounting Research 20(4): 805833.

Simunic, D. A. 1980. The pricing of audit services: Theory and evidence. Journal of Accounting Research 18(1): 161-190.

Slemrod, J. 2004. The economics of corporate tax selfishness. National Tax Journal 57: 877-899.

Sohn, S., E. Lee, K. Chung. 2008. The effect of audit hour on the management's revision of annual reported earnings. Korean Accounting Journal (printed in Korean): 1-30.

Stickney, C., McGee, V. 1982. Effective corporate tax rates: the effect of size, capital intensity, leverage, and other factors. Journal of Accounting and Public Policy 1(2): 125-152. 


\section{APPENDIX A}

\begin{tabular}{|c|c|c|}
\hline Year & Corporate tax base (million in KRW) & Statutory tax rate in Korea (\%) \\
\hline \multirow[b]{2}{*}{$2000 \sim 2001$} & above 100 & 28 \\
\hline & below 100 & 16 \\
\hline \multirow{2}{*}{ 2002 2004 } & above 100 & 27 \\
\hline & below 100 & 15 \\
\hline \multirow{2}{*}{$2005 \sim 2007$} & above 100 & 25 \\
\hline & below 100 & 13 \\
\hline \multirow{2}{*}{2008} & above 200 & 25 \\
\hline & below 200 & 11 \\
\hline \multirow{2}{*}{2009} & above 200 & 22 \\
\hline & below 200 & 11 \\
\hline \multirow{2}{*}{2010} & above 200 & 22 \\
\hline & below 200 & 10 \\
\hline
\end{tabular}




\section{NOTES}

